\title{
Development of an Internet of Things (IoT) System for Measuring Agricultural Runoff Quantity and Quality
}

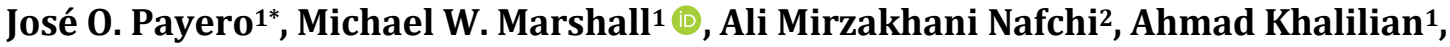 \\ Bhupinder S. Farmaha ${ }^{1}$, Rebecca Davis ${ }^{1}$, Wesley Porter ${ }^{3}$, George Vellidis ${ }^{3}$ \\ ${ }^{1}$ Clemson University Edisto Research and Education Center, Blackville, USA \\ ${ }^{2}$ Cornell University, Ithaca, USA \\ ${ }^{3}$ University of Georgia, Tifton, USA \\ Email: *jpayero@clemson.edu
}

How to cite this paper: Payero, J.O., Marshall, M.W., Nafchi, A.M., Khalilian, A., Farmaha, B.S., Davis, R., Porter, W. and Vellidis, G. (2021) Development of an Internet of Things (IoT) System for Measuring Agricultural Runoff Quantity and Quality. Agricultural Sciences, 12, 584-601. https://doi.org/10.4236/as.2021.125038

Received: April 15, 2021

Accepted: May 28, 2021

Published: May 31, 2021

Copyright $\odot 2021$ by author(s) and Scientific Research Publishing Inc. This work is licensed under the Creative Commons Attribution International License (CC BY 4.0).

http://creativecommons.org/licenses/by/4.0/

(c) (i) Open Access

\begin{abstract}
Runoff is an important component of the water balance of agricultural fields. Accurate measurement or estimation of agricultural runoff is important due to its potential impact on water quantity and quality. Since runoff from agricultural fields is sporadic and is often associated with irrigation and/or intense rainfall events, manually measuring runoff and collecting water samples for water quality analysis during runoff events is inconvenient and impractical. In the fall of 2017, a field site was selected at the Clemson University Edisto Research and Education Center with the objective of developing, constructing, and testing an Internet of things (IoT) flume system to automatically measure runoff and collect water samples. In 2018, an automatic IoT system was developed and installed consisting of six stainless steel $\mathrm{H}$-flumes $(22.9-\mathrm{cm})$, which measured runoff from six adjacent research plots under two different cultural regimes (cover crop and no cover crop). An electronic eTape sensor was installed in the flume and used to measure the water level or the flume's head. Open-source electronic (Arduino) devices and a cloud-based platform were then used to create a wireless sensor network and IoT system to automatically record the amount of runoff (hydrograph) coming from each section, collect water samples and transmit the data to a Cloud server (Thingspeak.com) where the data can be viewed remotely in real-time. The IoT flume system has been operating successfully and reliably for more than two years.
\end{abstract}

\section{Keywords}

Flume, Runoff, Water Quality, Cover Crop, Erosion 


\section{Introduction}

Runoff is an essential process in agricultural production since it affects the amount of rainfall water retained in the field and available to grow crops. Runoff can also cause soil erosion, transport soil particles, soil nutrients, and pesticides that can contaminate water sources while degrading soil structure, health, and productivity over time. Because of these potential effects, it is crucial to quantify the quantity, quality, and timing of agricultural runoff. However, measuring runoff in the field is difficult since runoff events are typically linked to sporadic and unpredictable rainfall events. Therefore, much effort has been devoted to developing and using models to estimate runoff using local rainfall data [1]-[6]. Although these models can be useful for a variety of practical, real-world applications, actual field measurements are still required to accurately characterize the impact of specific local conditions or farming practices on runoff quantity and quality and evaluate and calibrate existing models under local conditions.

Over the years, a variety of techniques have been used to measure runoff. Most of these techniques involve directing the runoff water to an outlet and having the water pass through a control structure where the water flow has a unique relationship between flow rate and water level. Therefore, the runoff flow rate can be determined by simply measuring the water level at the control structure. The control structure is usually some type of flume or weir [5] [7] [8] [9] [10] [11], but other structures, such as rectangular culverts have also been used [12]. Accurate determination of runoff volume using control structures requires the continuous recording of the water level, which is usually achieved using a stage-level recorder [7] [8] [9] [11] or a pressure transducer [4] [10] [13].

Rather than using a control structure, other researchers have used different ways of measuring runoff. For example, they have used a system incorporating a sump pump with a mercury float switch and a water meter [14], a system utilizing a tipping-bucket [15] [16], a system measuring the speed of water flow [17], or a system using a sink-plot [18]. Also, since there are many variables that affect runoff, such as slope, soil and plant conditions, and rainfall that cannot be adequately controlled in the natural environment, many researchers have measured runoff under field and laboratory conditions using rainfall simulators [19]-[24].

There are sampling methods that have been used to collect composite and discrete water samples for characterizing runoff water quality [11]. These sampling methods include autosamplers [11] [14], pumps [13], perforated pipe samplers [15], turnable water samplers [16], wheel samplers, silt collection aprons, silt collection pits, runoff sample storage tanks, and slot samplers [8].

Manually measuring runoff and collecting water samples for water quality analysis during runoff events is inconvenient and impractical, especially in remote agricultural settings. Therefore, there is a need for effective and affordable systems to measure runoff, collect water samples, and transmit data to the Internet. There have been considerable advances in open-source electronics, wireless communication, and Cloud computing technologies in recent years. These 
technologies could be integrated to develop an Internet of things (IoT) system [25] to collect, transmit, and visualize field data in real-time. In previous studies, our research team developed IoT systems for soil moisture monitoring and irrigation automation [26] [27] [28] that could be adapted for measuring runoff. Therefore, the objective of this project was to develop, construct, and test an Internet of things (IoT) flume system to measure runoff and collect water samples automatically. In this project, the IoT system was needed to measure and compare runoff quantity and quality from six adjacent research plots under two different cultural practice regimes (cover crop and no cover crop).

\section{Methods}

\subsection{Research Site Description and Field Layout}

The research site is located field studies were conducted at the Clemson University Edisto Research and Education Center, near Blackville, South Carolina $\left(33^{\circ} 20^{\prime} 48^{\prime \prime} \mathrm{N}, 81^{\circ} 18^{\prime} 19^{\prime \prime} \mathrm{W}\right)$. Blackville is located in a humid environment with an average annual precipitation of $1,198 \mathrm{~mm}$ and average annual maximum and minimum air temperatures of $25.6^{\circ} \mathrm{C}$ and $11.7^{\circ} \mathrm{C}$, respectively [29]. The site selected for this study was the northern half of a larger field that was irrigated by a 3 -span center pivot. The field was divided into six 1-acre (0.405-ha) sections. In three of the sections, cereal rye (Secale cereal L. "Wrens Abruzzi") cover crop was planted. Natural vegetation was allowed to grow during the winter in the remaining sections. The cover crop and the natural vegetation were terminated using herbicides in the spring and a cash crop (e.g., cotton or soybean) was planted in early May of each year.

The aerial image of the field site is shown in Figure 1(a) with the demarcations between plots and soil types. The elevation map of the field with the plot dimensions and corresponding percent slope is also shown in Figure 1(b). Soil variation is typical in the coastal plain of South Carolina. The field site had five distinct soil types (Figure 1(a)). According to the Web Soil Survey [30], the soils represented in the site were Barnwell Loamy Sand (71.6\%), McColl Loam (15.3\%), Wagram Sand (9.7\%), Dunbar Sandy Loam (3.2\%), and Neeses Loamy Sand $(0.3 \%)$.

The total field dimensions were $187 \mathrm{~m} \times 142 \mathrm{~m}$ with an area of $27,360 \mathrm{~m}^{2}$. Each field section was $137 \mathrm{~m} \times 31 \mathrm{~m}$, for a total area of $4164 \mathrm{~m}^{2}$. The field section slopes ranged from $1.8 \%$ to $3.4 \%$, with overall elevation decreasing from the northwest to the southeast corner of the field. The lowest point was at the southern edge of each section; therefore, flumes (one per field section) were installed at the lowest point along the southern edge of each section. A perimeter berm was built along each plot to prevent runoff water from entering from an adjacent plot and to redirect all the runoff from each section flume. A drainage ditch for the water exiting the flumes was constructed along the southern edge of the field to an existing main drain ditch along the eastern edge of the field. 


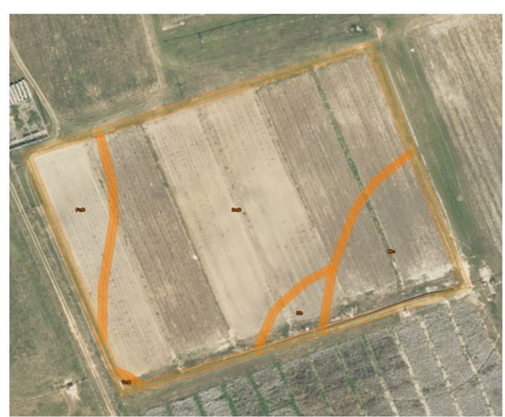

(a)

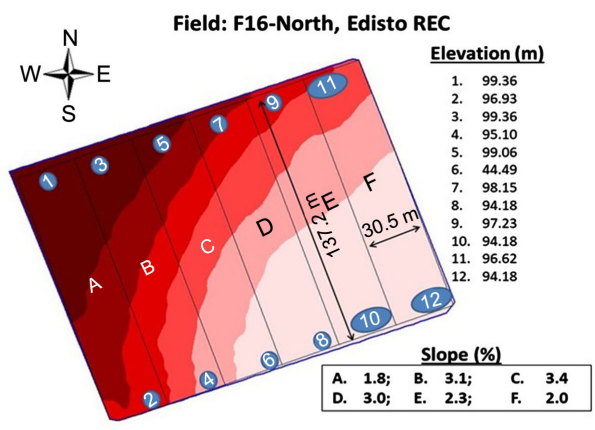

(b)

Figure 1. (a) Image of the flume field site. The yellow lines delineate soil types; (b) Elevation map and plot layout for the flume field.

\subsection{Flume Design, Construction, and Calibration}

In order to the design and construction of the correct flume size and dimensions for the expected peak runoff needed to be quantified at the research site. A hydrologic simulation was conducted using the WinTR-55 model (version 1.00.10). This was developed by the Natural Resources Conservation Service to model the hydrology of small watersheds [31]. The simulation for Barnwell County (NOAA14 County) resulted in a peak flow of $27.18 \mathrm{l} / \mathrm{s}$ for a rainfall event of a return of 2 years $(91.4-\mathrm{mm})$. For this peak flow, it was determined that a 22.9-cm H-Flume would be adequate following guidelines described in [32].

The H-flume constructed for this project was based on previous design specifications [33] (Figure 2). The engineering drawings were then created using the specifications as templates for fabricating the flumes (Figure 3 and Figure 4). The flumes were then constructed out of 16-gauge stainless steel sheets. One of the constructed flumes is shown in Figure 5. The constructed flumes included a steeling well to measure the water level in the flume (pressure head).

A discharge function relating the runoff flow rate to the measured flume head was developed (Figure 6) from data tables for a 22.9-cm H-Flume [32]. A 30-cm standard eTape liquid level sensor housed in a plastic casing (Figure 8(a)) (Adafruit Industries, NY) was used to quantify changes in the water level (flume head) of the steeling well. The eTape is a solid-state sensor with a resistive output that varies with fluid depth. The output from the eTape (resistance) was inversely proportional to the height of the liquid (i.e., the lower the liquid level, the higher the output resistance; the higher the liquid level, the lower the output resistance).

Before installing the flumes in each field section, the eTapes were calibrated to determine the relationship between output resistance and the flume water level. The eTape was placed in a graduated cylinder and the water level was changed in the cylinder, and the eTape signal output was recorded. The output of the eTape was measured with a Feather MO microcontroller (Adafruit Industries, NY), which was programmed to record data to an SD card every 30 seconds. At each water level, data were collected for approximately 5 minutes, resulting in 

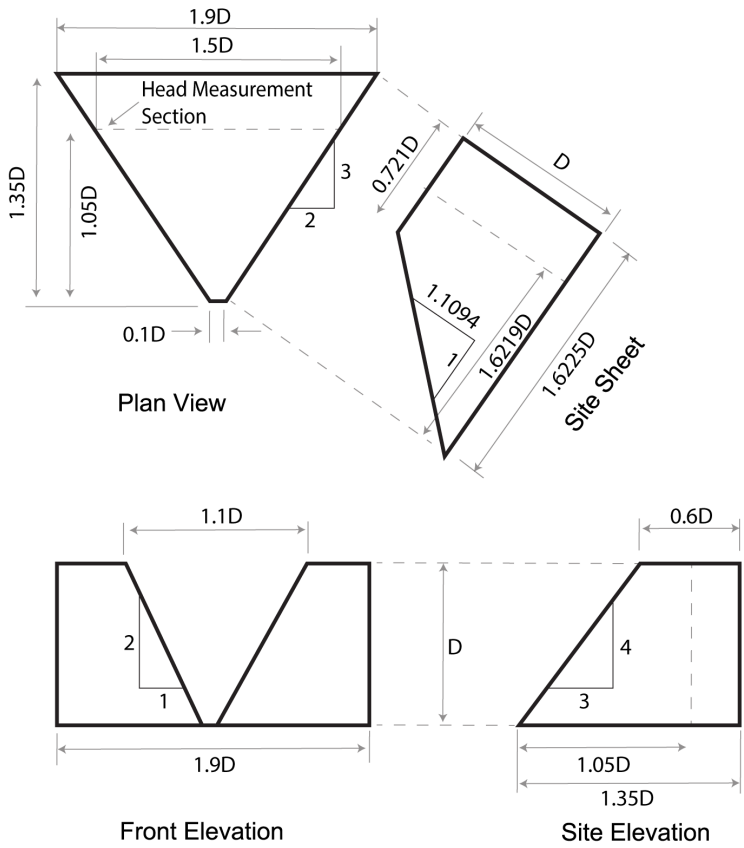

Figure 2. Design specifications for an H-Flume $(\mathrm{D}=22.9-\mathrm{cm})$, adapted from [32].
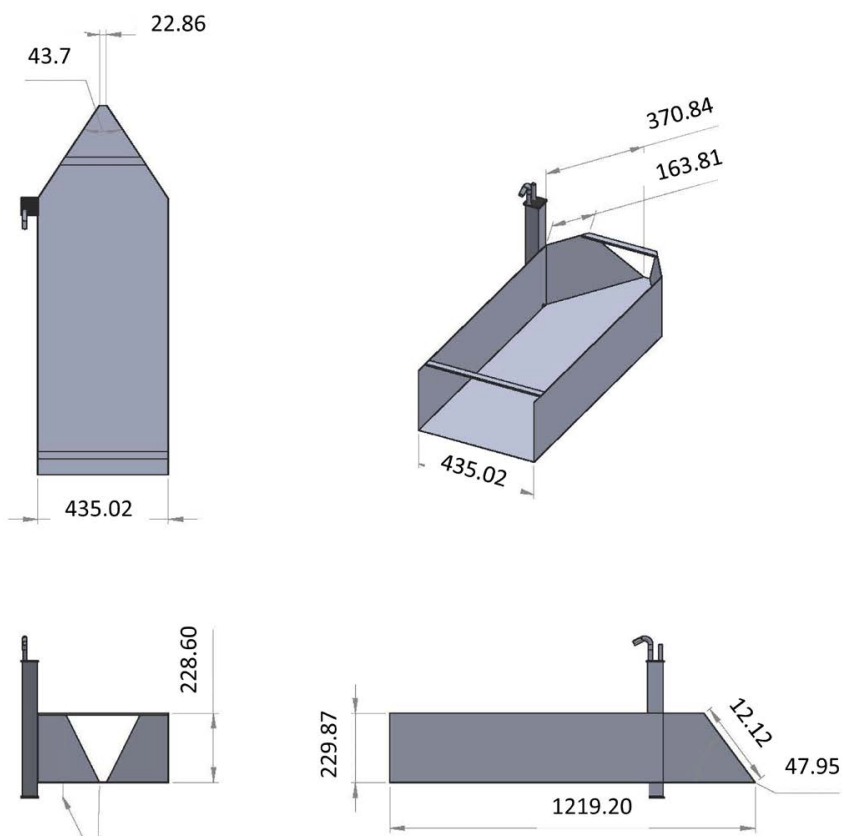

307.85

Figure 3. Engineering drawings for fabricating the H-Flumes $($ diameter $=22.9-\mathrm{cm})(\mathrm{di}-$ mensions are in $\mathrm{mm}$ ).

approximately 10 data points for each water level. The eTape linear relationship between the eTape resistance output and the water level is shown in Figure 7. From this calibration correlation, the relationship between water level and the sensor output was excellent $\left(\mathrm{R}^{2}=0.9999\right)$. In addition, the sensor output for a given water level was stable and repeatable. 


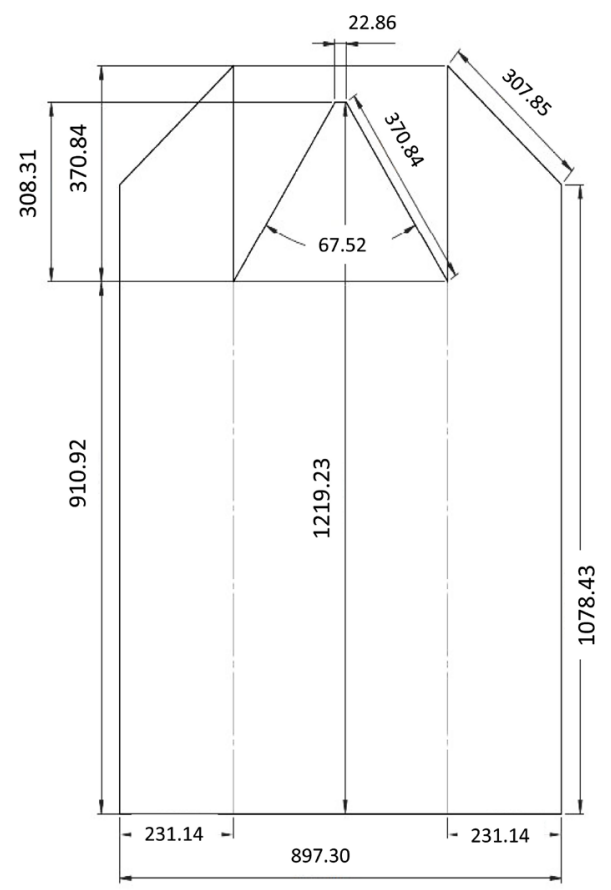

Figure 4. Engineering drawing showing an unfolded top view of how to cut and bend a sheet of metal to build the $22.9-\mathrm{cm}$ diameter $\mathrm{H}$-flume (dimensions are in $\mathrm{mm}$ ).

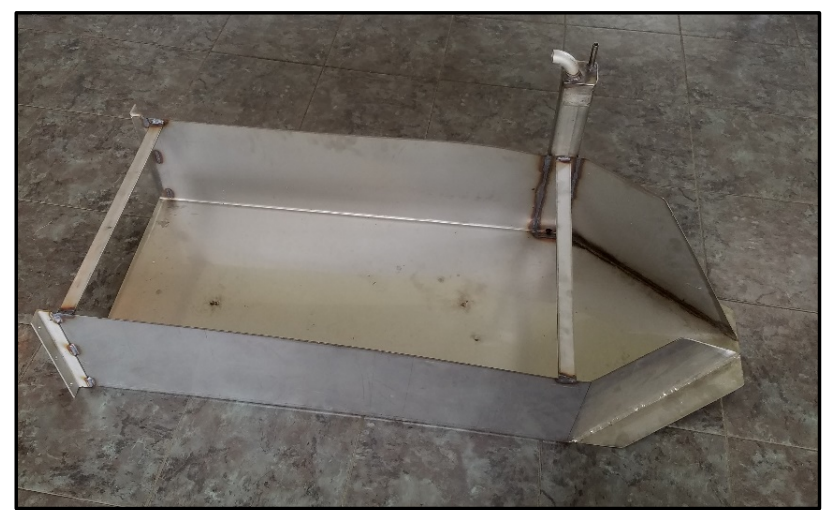

Figure 5. A completed stainless steel H-Flume ready for installation in the field site.

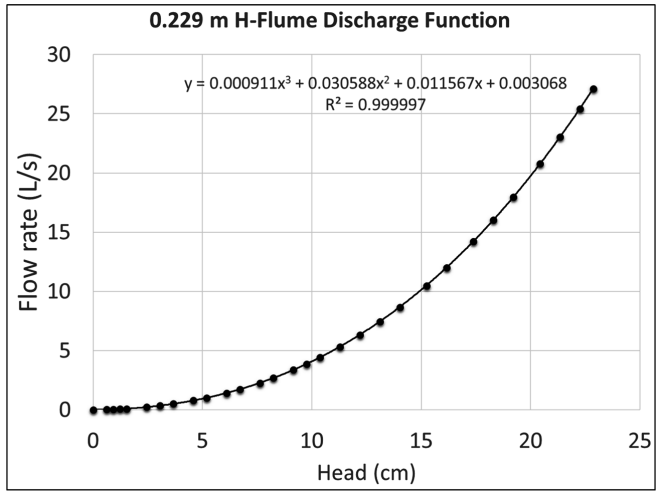

Figure 6. Relationship between the head $(\mathrm{cm})$ and flow rate $(\mathrm{L} / \mathrm{s})$ for a $22.9-\mathrm{cm} \mathrm{H}$-flume, adapted from [32]. 


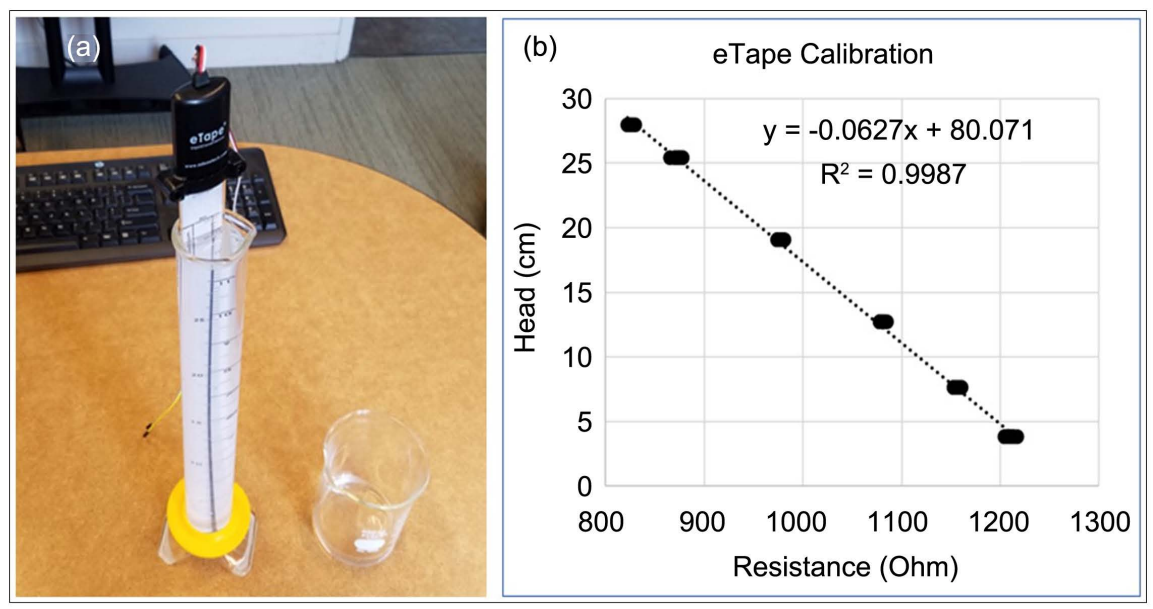

Figure 7. (a) Calibrating the eTape sensor using known water levels and (b) the resulting linear relationship between eTape resistance sensor output and water level (head).

\subsection{The Electronic Components Used in the IoT System}

The electronics for the flume IoT system were developed based on previous systems that were developed for soil moisture monitoring [26] [27]. The system was built using low-cost, open-source electronic components and consisted of a wireless sensor network. Six End Nodes [EN] were installed at each flume and collected information (water level) and sent this information to a receiver or Coordinator via radio communication. The Coordinator receives the data from all the EN (one at a time to ensure collisions among the data streams do not happen) and sends the received data to the Cloud Server.

Figure 8 shows the basic electronic components of each EN (sender). These components included a micro-controller with an integrated radio transceiver, a power relay, and a solar charge controller. The micro-controller used in the project was a Feather M0 with RFM95 LoRa Radio-900 MHz-RadioFruit (Adafruit industries, NY). This is an Arduino compatible device that combines a microcontroller with a "Long Range (LoRa)" packet radio transceiver. The Feather M0 has an ATSAMD21G18 ARM Cortex M0 processor, clocked at $48 \mathrm{MHz}$, and 3.3 V logic. The micro-controller was integrated with an Adalogger FeatherWing-RTC + SD Add-on for All Feather Boards (Adafruit industries, NY). This board was available with a real-time-clock (RTC) and a drive slot for an external SD card. The microcontroller and the Adalogger were mounted on an Assembled Terminal Block Breakout FeatherWing for all Feathers (Adafruit industries, $\mathrm{NY}$ ), which allows the sensor and relay wires to be connected to the microcontroller.

The power relay consisted of a 1 channel DC $3 \mathrm{~V}$ relay High-Level Driver Module (Amazon.com). The relay is used to switch a $12 \mathrm{~V}$ pump (Rule IL280P 12 Volt 280 GPH Inline and Submersible Pump, Amazon.com) on and off using the microcontroller to collect water samples during runoff events. During each rainfall event, the motor on the pump is activated for $20 \mathrm{~s}$ for every $10 \mathrm{~m}$ runoff 


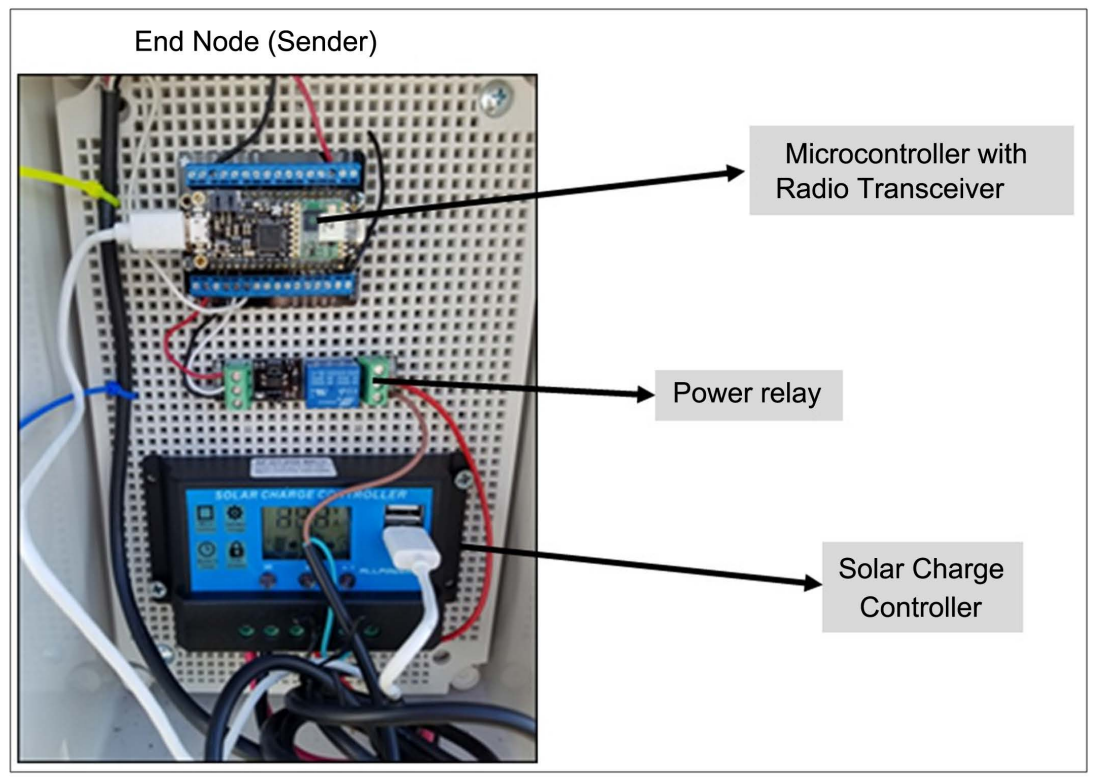

Figure 8. The electronic components of an end node.

period and withdraws a water sample from the flume and transfers it to an 18.9 L glass carboy collection vessel. A composite water sample was then collected from the carboy after the rainfall event and stored in a cooler later water quality analysis. A representative sample from each run-off event is crucial for accurate water quality analysis. For example, [33] found that the concentration of nutrients and pesticides in runoff waters from small agricultural watersheds varied as much as 100 -fold from one storm event to another, and even two-fold from one high water flow to another during the same major storm. Therefore, having an automated system to collect small subsamples during the duration of the runoff event would create a more representative sample for each event.

Power to the EN and the $12 \mathrm{~V}$ pump (using the power relay) was supplied using a $12 \mathrm{~V}$ car battery, which is charged by a Newpowa 100 Watts solar panel (Amazon.com). A 20 Amp solar charge controller (Amazon.com) was used to prevent overcharging the battery. The solar charger controller also had two USB ports. One of these USB ports was used to energize the microcontroller. The microcontroller was programmed to measure the water level every 10 minutes, collect a water sample if a runoff event is occurring, save the timestamp and the water lever measurement to an SD card, and send the data via radio communication to the Coordinator [2]. Each EN is assigned a unique ID and is programmed to send data to the Coordinator only during a specified time window when the Coordinator was not busy, to avoid data collision and loss among different EN.

The Coordinator (receiver) electronic components are shown in Figure 9. These components included a microcontroller with a radio transceiver and Adalogger FeatherWing-RTC+SD, which are the same components as previously described for the EN. The Coordinator also included a microcontroller with a 


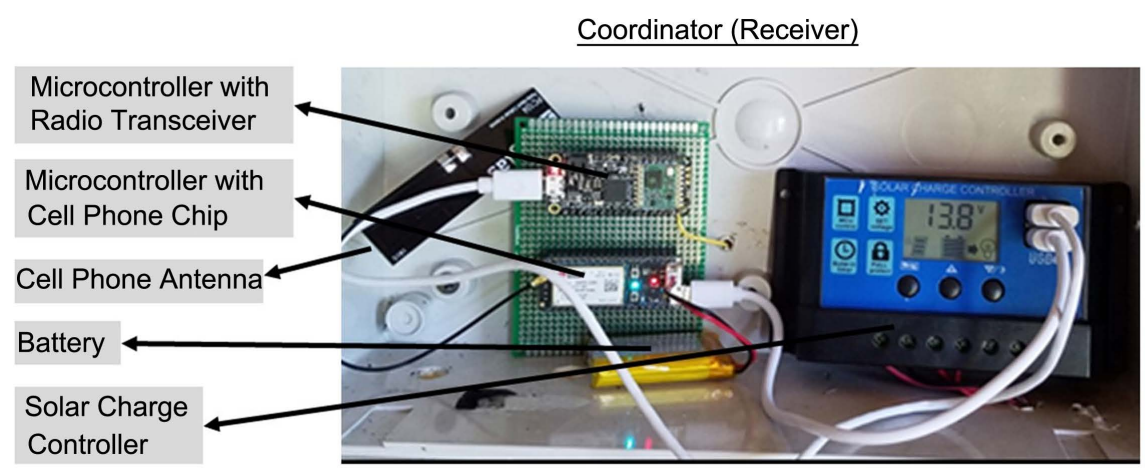

Figure 9. The electronic components contained in the coordinator position.

cell phone chip (Electron 2G/3G [Particle Industries, Inc.]). The Electron 2G/3G device combines an STM32F205RGT6 $120 \mathrm{MHz}$ ARM Cortex M3 microcontroller with a U-Blox SARA-U260/U270 (3G with $2 \mathrm{G}$ fallback), G350 (2G), or R410M (LTE Cat M1) cellular module. Additional components of the Coordinator included a cell phone antenna and a LiPo battery for the Electron 2G/3G and a solar charge controller. The power supply for the Coordinator was provided by a $12 \mathrm{~V}$ deep cycle marine battery. The battery was recharged using a solar panel, as previously described for the EN. The microcontroller with a radio transceiver component of the Coordinator receives the data from each of the EN, saves the data to the SD card, and then transmits the data to the Electron 2G/3G device via UART two-wire communication using the $\mathrm{Rx}$ and $\mathrm{Tx}$ pins of the two microcontrollers. The Electron $2 \mathrm{G} / 3 \mathrm{G}$ device transmits the data to the Cloud Server on the Internet.

\subsection{Field Installation}

A flume was installed at the lowest point on the southern edge of each of the six research plots. The lowest point in the research plot was located using land surveying equipment. The Coordinator was placed at the same location as Flume 1 to be able to share the same battery and solar panel (Figure 10). Figure 11 shows that each flume was installed on top of a $5-\mathrm{cm}$ thick concrete base. Two vertical wooden boards were installed at the sides of the flume inlet which directed the runoff water towards the flume. Large rocks were placed to prevent erosion around the flume. The water pump was then attached to one of the wooden boards ensuring that the pump intake was level with the bottom of the flume. The electronics were placed inside a plastic instrument box (NEMA environmental enclosure). The instrument box and the solar panel were mounted to a wooden post. A $12 \mathrm{~V}$ deep cell marine battery was placed inside a plastic box on the ground, next to the wooden post. The eTape was placed inside the stilling well. A $1.25-\mathrm{cm}$ hole was drilled into the sidewall of the flume adjacent to the stilling well. This small opening allowed runoff water to enter the steeling well and raise the water level inside the well to the same corresponding height as in the flume (head). 


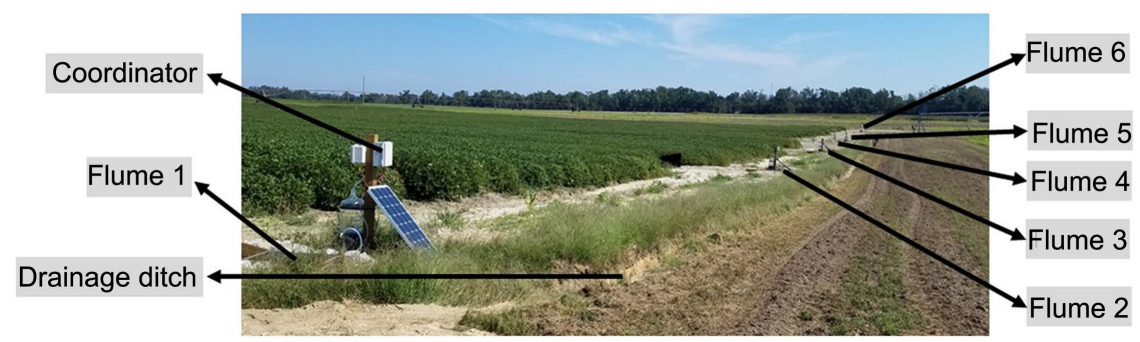

Figure 10. The layout of the coordinator and nearby end nodes (flumes) positions in the field.

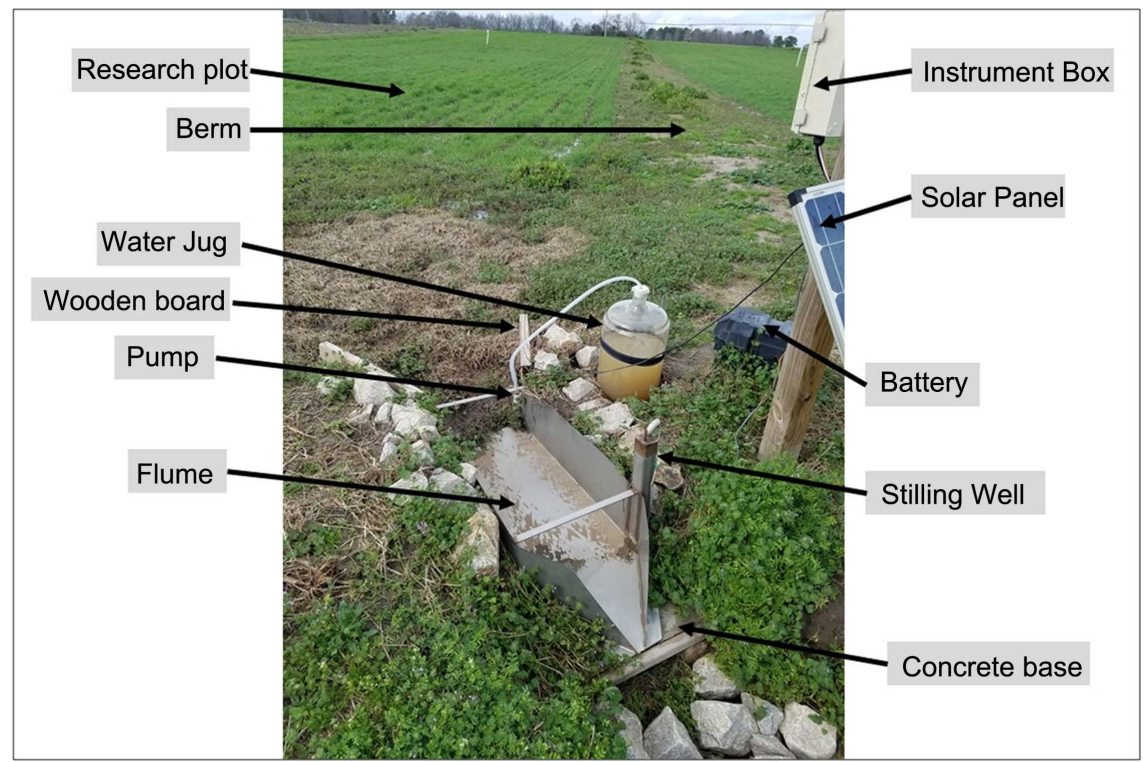

Figure 11. Field components setup at one of the End Nodes (Flumes).

Local rainfall information is critical information for the interpretation of runoff data. A weather station was installed near the field (as one of the EN of the wireless network) outside the area irrigated by the center pivot (Figure 12). In this study, the weather station collected the following environmental parameters: air temperature, relative humidity, solar radiation, and rainfall. The IoT weather station was built using commercially available sensors and parts. The electronics and software for data collection and communication were also developed using open-source components. The data collection and communication system for the weather system was like the one described for the EN including utilizing the 10-minute communication window with the Coordinator.

\subsection{Data Storage and Visualization}

ThinkSpeak (thinkspeak.com) was utilized as the Cloud platform service for the IoT project which allowed data hosting, aggregation, visualization for the live data streams in the cloud. This service allows users to send data from internet connected devices to the Cloud platform and create instant visualizations of live data and, ultimately, send decision-making alerts. The system is also integrated 


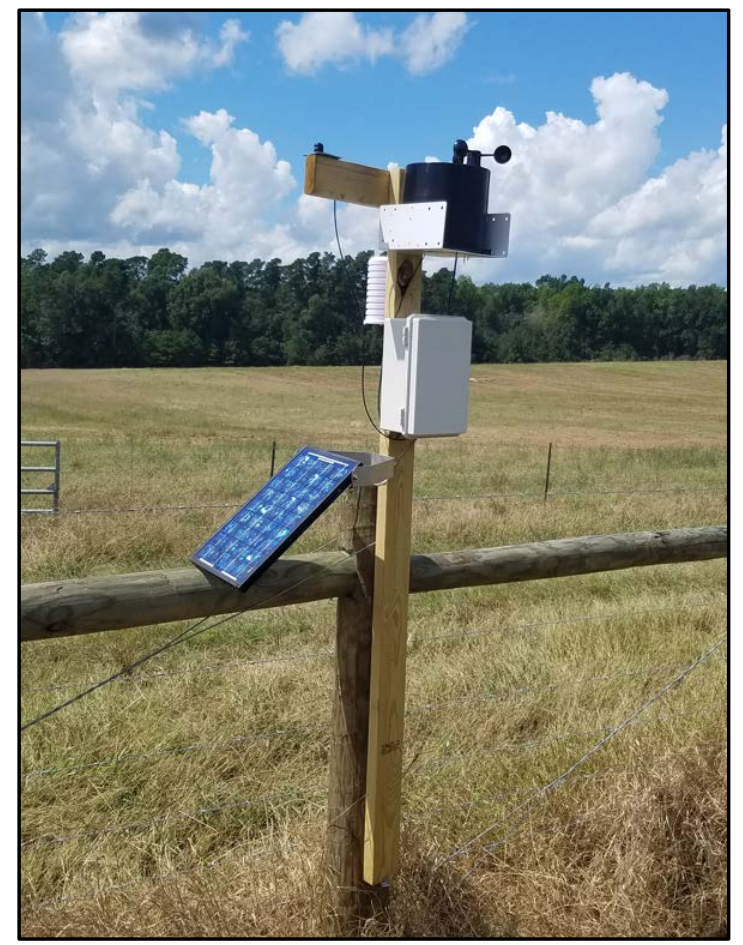

Figure 12. The IoT weather station located near the field site.

with MATLAB, which performs data analysis. The service offers a free license for small non-commercial projects, but the service is limited to 4 channels and 3 million messages/year (data points). Therefore, an academic license was purchased for this IoT project which provided the capability of 250 channels and 33 million messages/year. In addition to visualizing the data using the ThinkSpeak website, several mobile Apps were available that allowed visualizing data uploaded to the Thinkspeak channels on a handheld device, such as a cell phone. The ThinkView app was selected and used for this project. The App is available on both Android and iOS platforms.

\subsection{Cost of the System}

The cost of each of the IoT system components is provided in Table 1 . The cost of the components, fabrication, and installation of each flume, the cost of each EN, the Coordinator, and data communication and visualization are shown. Other costs including labor needed to design, assembly, programming, and installation of components, and shipping and handling were not included in the breakdown.

The cost of fabricating and installing each flume was around $\$ 200$, a total of $\$ 1200$ for the six flumes. The cost of each flume EN was around $\$ 503$, a total of $\$ 3018$ for the six flumes. This cost includes the data logging and data communication system, the eTape sensor, the pump, and the power supply system. The power supply (battery, solar panel, and solar charge controller) accounted for around $44 \%$. The cost of the Coordinator was $\$ 385$. However, the cost includes 
Table 1. Cost of flumes and IoT system components used in the IoT project.

\begin{tabular}{|c|c|c|c|c|}
\hline Component & Item & Quantity & Unit Cost (US\$) & Total (US\$) \\
\hline \multirow{3}{*}{ Flume } & Materials & 1 & $\$ 80.00$ & \multirow[b]{3}{*}{$\$ 200.00$} \\
\hline & Fabrication & 1 & $\$ 150.00$ & \\
\hline & Installation & 1 & $\$ 10.00$ & \\
\hline \multirow{15}{*}{ End Node } & Pump & 1 & $\$ 50.48$ & \\
\hline & eTape & 1 & $\$ 59.95$ & \\
\hline & 5 gal glass carboy & 1 & $\$ 46.00$ & \\
\hline & Solar panel $(100 \mathrm{~W})$ & 1 & $\$ 103.00$ & \\
\hline & Battery and battery case & 1 & $\$ 100.00$ & \\
\hline & Plastic Enclosure & 1 & $\$ 39.00$ & \\
\hline & Wooden post $\left(4^{\prime \prime} \times 4^{\prime \prime} \times 8^{\prime}\right)$ & 1 & $\$ 14.00$ & \\
\hline & Solar charge controller & 1 & $\$ 16.00$ & \\
\hline & $3 \mathrm{~V}$ power relay & 1 & $\$ 3.50$ & \\
\hline & Microcontroller/radio & 1 & $\$ 34.95$ & \\
\hline & Adalogger FeatherWing & 1 & $\$ 8.95$ & \\
\hline & Terminal Block & 1 & $\$ 14.95$ & \\
\hline & Coin cell battery & 1 & $\$ 0.95$ & \\
\hline & SD/MicroSD card & 1 & $\$ 9.95$ & \\
\hline & Stacking headers & 1 & $\$ 1.25$ & $\$ 502.93$ \\
\hline \multirow{10}{*}{ Coordinator } & Microcontroller/radio & 1 & $\$ 34.95$ & \\
\hline & Adalogger FeatherWing & 1 & $\$ 8.95$ & \\
\hline & Coin cell battery & 1 & $\$ 0.95$ & \\
\hline & SD/MicroSD card & 1 & $\$ 9.95$ & \\
\hline & Stacking headers & 1 & $\$ 1.25$ & \\
\hline & Solar panel $(100 \mathrm{~W})$ & 1 & $\$ 103.00$ & \\
\hline & Battery and battery case & 1 & $\$ 100.00$ & \\
\hline & Plastic Enclosure & 1 & $\$ 39.00$ & \\
\hline & Solar charge controller & 1 & $\$ 16.00$ & \\
\hline & Electron 2G/3G Starter Kit & 1 & $\$ 71.35$ & $\$ 385.40$ \\
\hline Data storage/ & ThinkSpeak annual fee & 1 & $\$ 250 /$ year & $\$ 250 /$ year \\
\hline \multirow[t]{2}{*}{ Visualization } & Cell phone data plan & 1 & $\$ 60 /$ year & $\$ 60 /$ year \\
\hline & ThinkView App & 1 & Fee & Free \\
\hline
\end{tabular}

the power supply system (\$219), which was $57 \%$ of the cost. The Coordinator was placed in the same location as Flume 1 and was able to share the same power supply used for the operation of Flume 1. Therefore, the actual cost for the Coordinator was $\$ 166$. 
If the Coordinator was located at a different location than an EN, it would have needed an independent power supply. However, since the Coordinator does not need to operate a pump, the power requirements would be much less than the EN; therefore, it would need a smaller capacity battery and solar panel.

In addition to the one-time cost of the equipment setup, additional ongoing costs are associated with data communication and visualization. The recurring costs included the ThingSpeak license and cell phone data plan. Since the free ThinkSpeak license was not sufficient for the needs of this project, an academic license was purchased for $\$ 250 /$ year. The data plan needed for the Coordinator was $\$ 5 /$ month or $\$ 60 /$ year.

\section{Results and Discussion}

The IoT system was developed, constructed, and deployed in the field to automatically quanitify runoff amount and collect water quality samples. For example, a runoff hydrograph was recorded and generated on ThingSpeak website for Flume \#3 during a runoff event that occurred on Feb 25-26, 2020 (Figure 13). The ThinkSpeak website allows users to create channels to receive data from field sensors and graphically display those data points. Each channel provided by ThinkSpeak can represent up to eight fields and each field can be used to store and display a set of data, such as real-time data output from a field sensor and/or the results from a calculation. Each collected data point was timestamped as it was received in the Coordinator before transmitting to the ThingSpeak database. For this project, data from each flume was sent using a separate channel for EN. For each flume site in the field, three data items were sent over the internet and populated the corresponding prepopulated fields in ThingSpeak. For this project, items included water level measured by the eTape

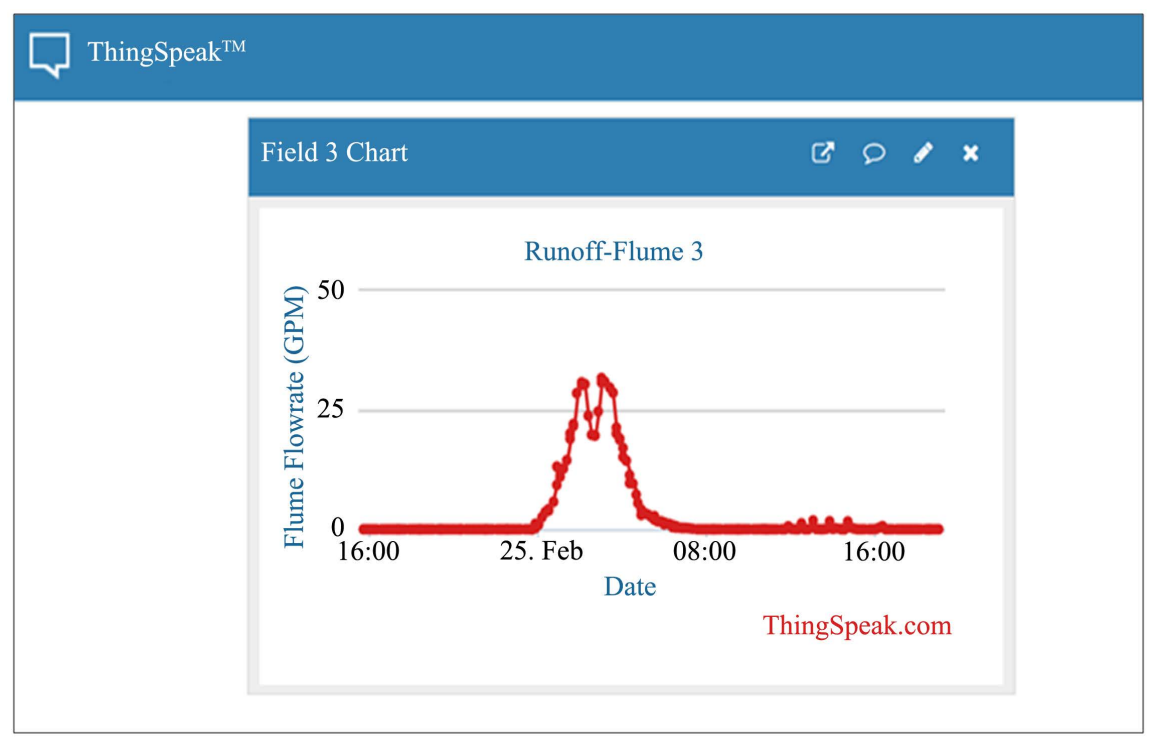

Figure 13. Screenshot of the ThinkSpeak website showing flume flowrate in gallons per minute (GPM) during a runoff event. 
(eTape head), the water level on the flume (flume head), and the calculated flow rate (flow rate). Since the zero value of the eTape was located below the bottom of the flume, it would always read an eTape head value greater than zero. Therefore, the zero-reading had to be subtracted from the output collected during the run-off event to determine the flume head. The fume head was then used to calculate the flow rate during a run-off event.

After the data was stored in ThinkSpeak, the user could download the data into a text file (csv format). The csv files could be then processed using a program, such as Microsoft Excel. For example, Figure 14 shows data collected from a runoff event measured by Flume \#6, which occurred on 9/28/2018. In this case, the csv data file was downloaded from ThingSpeak and further processed in Excel to create a runoff hydrograph and a cumulative runoff curve that showed this event produced a total runoff of $26,895 \mathrm{~L}$ during $150 \mathrm{~min}$ ( $2.5 \mathrm{hrs})$.

The ThinkView cell phone App was also used in this project to visualize data collected from each flume in real-time. The features on the ThinkView App allowed basic data viewing; however, changing the date range, flow rate on the graph, or other queries were not possible. Figure 15 shows screenshots of the ThinkView App. The first screenshot (left) shows the channels available for display. By selecting one of these channels, the App provided a graphical display of the data for that channel.

In addition to measuring runoff, another design feature of the IoT system was the automatic collection water samples during runoff events for later water quality analysis. The IoT runoff system performed as expected. For example, Figure 16 shows a water sample being collected at one of the flumes during a runoff event. The water sample was cloudy and noticeably loaded with suspended solids that resulted from soil erosion from the field site. The submersible pump (Rule IL280P, Rule Store) was used for water sample collection during run-off events. The unit performed well even when the sample contained a high sediment load.

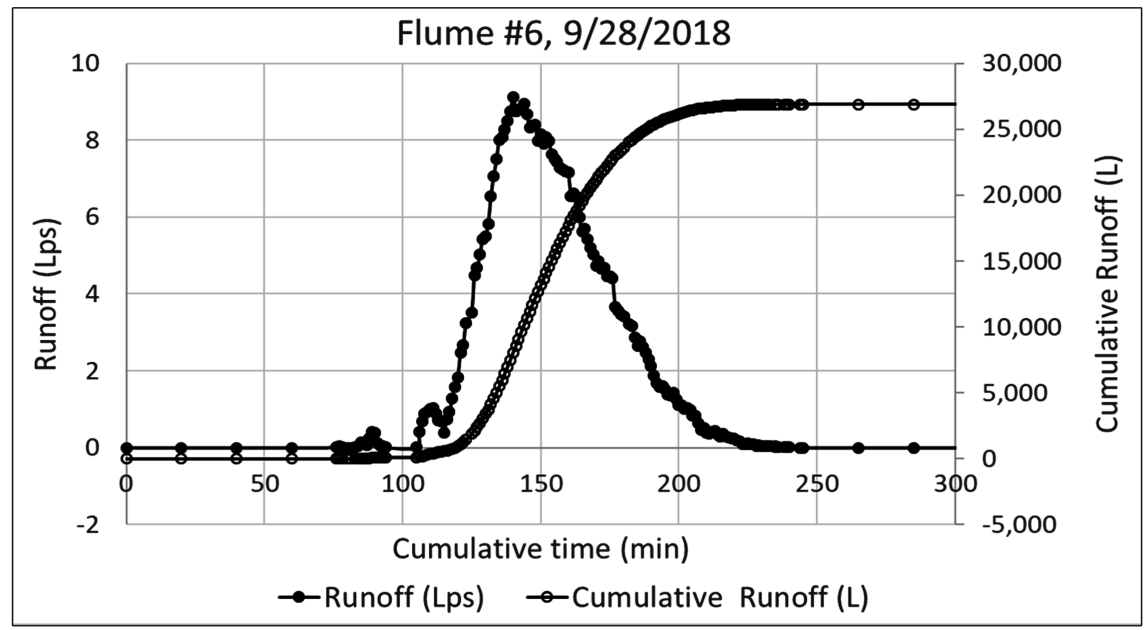

Figure 14. Runoff hydrograph and cumulative runoff measured by Flume \#6 during a 150 min runoff event on 6/28/2018 in blackville, SC. 

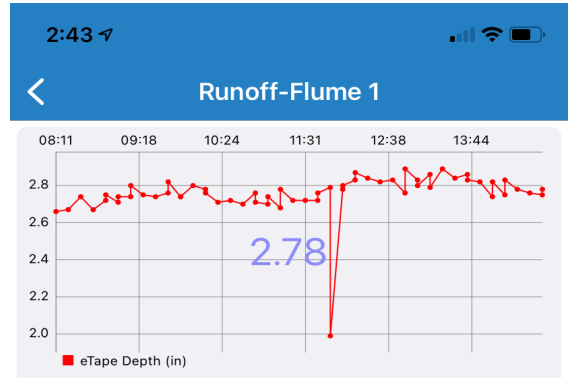

Min 1.99 on 03 May 11:51 Max 2.89 on 03 May 12:51
Last 2.78 on 03 May 14:41

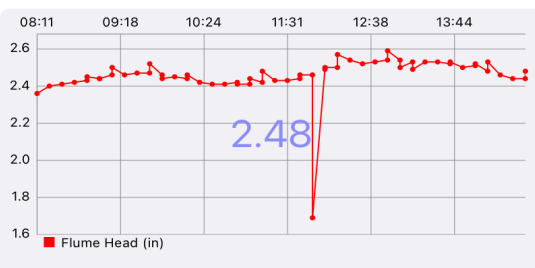

Min 1.69 on 03 May 11:51 Max 2.59 on 03 May 12:51

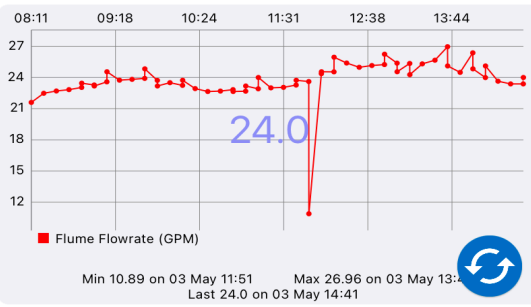

Last 24.0 on 03 May 26.96 14:41
Lay

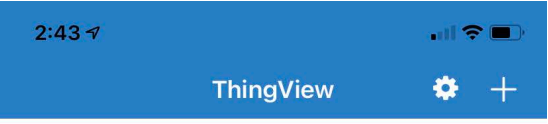

BookhartcC

BookhartNCC

BatesCC

BatesNCC

Soil Moisture-Flume2

Soil Moisture-Flume3

Soil_Moisture_ElumeA

Access time presets and remove Ads for $\$ 1.99$

Figure 15. Screenshots of runoff from flume \#1 on the ThinkView cell phone App.

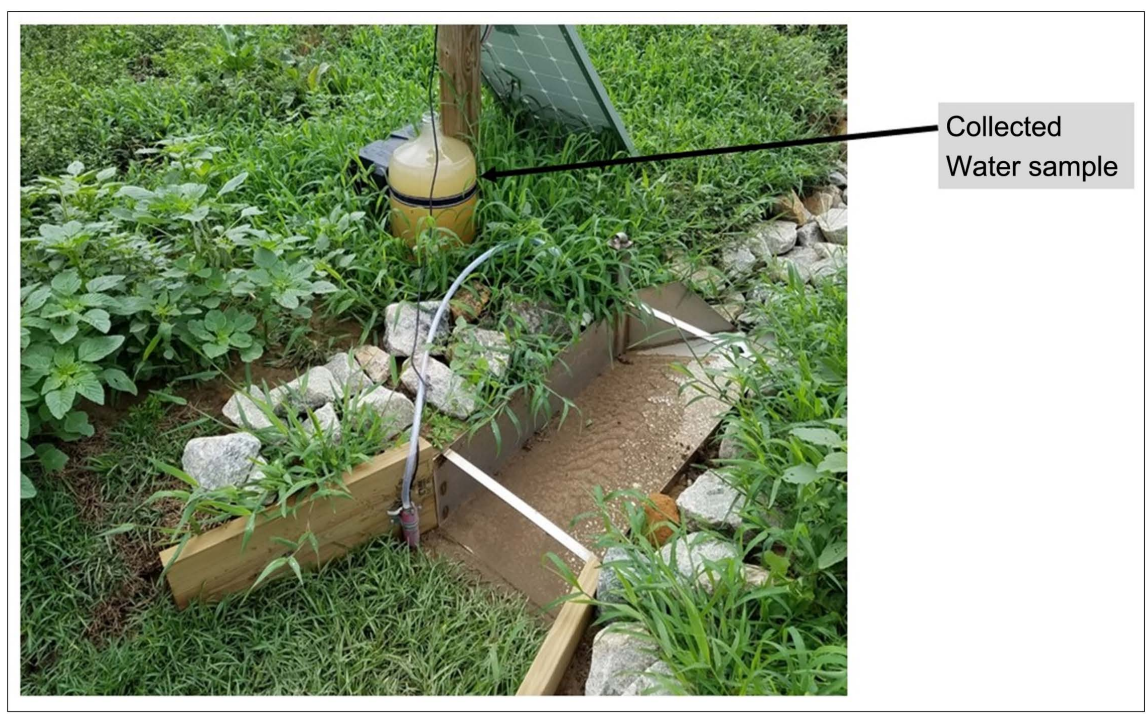

Figure 16. A composite water sample is collected from a $\mathrm{H}$-flume during a runoff event.

\section{Conclusion}

The IoT system was developed and tested under field conditions. It automatically measured runoff and collected water quality samples. The results from the 
project showed that an IoT system can successfully quantify in real-time the impact of a cover crop on agricultural runoff quantity and quality. The system utilized low-cost open-source Arduino (https://www.arduino.cc) based hardware and software electronics. A web-based and App-based Internet Cloud platform was also successfully used for data storage and real-time visualization. This lowcost IoT system was effective for water runoff and quality monitoring and has the potential for long-term deployment in agricultural production systems. Future research includes measuring and analyzing the water quality and quantity collected over time from the IoT system.

\section{Acknowledgements}

Technical Contribution No. 6978 of the Clemson University Experiment Station. This material is based upon work supported by NIFA/USDA, under project number SC-1700592, 1700593. Additional funding provided by USDA-NRCS Project number 69-3A75-17-274.

\section{Conflicts of Interest}

The authors declare no conflicts of interest regarding the publication of this paper.

\section{References}

[1] USDA (1986) Urban Hydrology for Small Watersheds; Technical Release No. 55 (TR-55), Natural Resources Conservation Service, 164.

[2] Chanasyk, D.S., Mapfumo, E. and Willms, W. (2003) Quantification and Simulation of Surface Runoff from Fescue Grassland Watersheds. Agricultural Water Management, 59, 137-153. https://doi.org/10.1016/S0378-3774(02)00124-5

[3] Bicknell, B.R., Imhoff, J.C., Kittle, J.L., Jobes, T.H. and Donigian, A.S. (2005) HSPF Version 12.2 User's Manual.

[4] Devi, G.K., Ganasri, B.P. and Dwarakish, G.S. (2015) A Review on Hydrological Models. Aquatic Procedia, 4, 1001-1007.

https://doi.org/10.1016/j.aqpro.2015.02.126

[5] Gregoretti, C., Degetto, M., Bernard, M., Crucil, G., Pimazzoni, A., De Vido, G., Berti, M., Simoni, A. and Lanzoni, S. (2016) Runoff of Small Rocky Headwater Catchments: Field Observations and Hydrological Modeling. Water Resources Research, 52, 8138-8158. https://doi.org/10.1002/2016WR018675

[6] Sitterson, J.C., Knightes, K., Parmar, K., Muche, M. and Avant, B. (2017) An Overview of Rainfall-Runoff Model Types. U.S. Environmental Protection Agency, Athens.

[7] Wani, S.P., Singh, P. and Pathak, P. (1999) Methods and Management of Data for Watershed Research: Technical Manual for the Training Workshop, 15-26 November 1999, ICRISAT Center, Patancheru, India. Technical Manual No. 5. Patancheru 502 324, International Crops Research Institute for the Semi-Arid Tropics, Andhra Pradesh.

[8] McGregor, K.C., Greer, J.D., Gurley, G.E. and Bolton, G.C. (1969) Runoff Production from North Mississippi Loessial Soils. Bulletin 777. US Department of Agriculture and the Mississippi Agricultural Experiment Station, $30 \mathrm{p}$. 
[9] Osborn, H.B. and Renard, K.G. (1970) Thunderstorm Runoff on the Walnut Gulch Experimental Watershed, Arizona, USA. IASH-Unesco-Symposium on the Results of Research on Representative and Experimental Basins, Wellington, December $1970,10 \mathrm{p}$.

[10] Ritsema, C.J., Stolte, J., Oostindie, K. and Van Den Elsen, E. (1996) Measuring and Modelling of Soil Water Dynamics and Runoff Generation in an Agricultural Loessial Hillslope. Hydrological Processes, 10, 1081-1089.

https://doi.org/10.1002/(SICI)1099-1085(199608)10:8<1081::AID-HYP413>3.0.CO; $\underline{2-\mathrm{N}}$

[11] Bartley, R., Roth, C.H., Ludwig, J., McJannet, D., Liedloff, A., Corfield, J., Hawdon, A. and Abbott, B. (2006) Runoff and Erosion from Australia's Tropical Semi-Arid Rangelands: Influence of Ground Cover for Differing Space and Time Scales. $H y$ drological Processes, 20, 3317-3333. https://doi.org/10.1002/hyp.6334

[12] Ree, W.O. and Crow, F.R. (1954) Measuring Runoff Rates with Rectangular Highway Culverts. US Department of Agriculture, Oklahoma Agricultural Experiment Station, Technical Bulletin No. T-51, 19 p.

[13] Striebel, T., Daub, J. and Herrmann, R. (1994) A Sampling Device for Measuring Physical and Chemical Characteristics of Urban Street Runoff. The Science of the Total Environment, 146-147, 515-523. https://doi.org/10.1016/0048-9697(94)90277-1

[14] Soultani, M., Tan, C.S., Gaynor, J.D., Neveu, R. and Drury, C.F. (1993) Measuring and Sampling Surface Runoff and Subsurface Drain Outflow Volume. Applied Engineering in Agriculture, 9, 447-450. https://doi.org/10.13031/2013.26008

[15] Khan, A.A.H. and Ong, C.K. (1997) Design and Calibration of Tipping Bucket System for Field Runoff and Sediment Quantification. Journal of Soil and Water Conservation, 52, 437-443.

[16] Zhao, S.L., Dorsey, E.C., Gupta, S., Moncrief, J.F. and Huggins, D.R. (2001) Automated Water Sampling and Flow Measuring Devices for Runoff and Subsurface Drainage. Journal of Soil and Water Conservation, 56, 299-306.

[17] Bonta, J.V. and Goyal, V.C. (2000) Comparison of Drip-Flow/Low-Flow Measuring Devices for Infiltrometer Runoff Measurements. Transactions of the ASAE, 43, 1489-1498. https://doi.org/10.13031/2013.3048

[18] Kidron, G.J. (2014) Sink Plot for Runoff Measurements on Semi-Flat Terrains: Preliminary Data and Their Potential Hydrological and Ecological Implications. Journal of Hydrology and Hydromechanics, 62, 303-308.

https://doi.org/10.2478/johh-2014-0032

[19] Greene, R.S.B. and Sawtell, G.R. (1992) A Collection System for Measuring Runoff and Soil Erosion with a Mobile Rainfall Simulator on Sealed and Stony Red Earth Soils. Australian Journal of Soil Research, 30, 457-463.

https://doi.org/10.1071/SR9920457

[20] Le Bissonnais, Y., Renaux, B. and Delouche, H. (1995) Interactions between Soil Properties and Moisture Content in Crust Formation, Runoff and Interrill Erosion from Tilled Loess Soils. Catena, 25, 33-46. https://doi.org/10.1016/0341-8162(94)00040-L

[21] Isensee, A.R. and Sadeghi, A.M. (1999) Quantification of Runoff in Laboratory-Scale Chambers. Chemosphere, 38, 1733-1744. https://doi.org/10.1016/S0045-6535(98)00390-7

[22] Benavides-Solorio, J. and MacDonald, L.H. (2001) Post-Fire Runoff and Erosion from Simulated Rainfall on Small Plots, Colorado Front Range. Hydrological 
Processes, 15, 2931-2952. https://doi.org/10.1002/hyp.383

[23] Humphry, J.B., Daniel, T.C., Edwards, D.R. and Sharpley, A.N. (2002) A Portable Rainfall Simulator for Plot-Scale Runoff Studies. Applied Engineering in Agriculture, 18, 199-204. https://doi.org/10.13031/2013.7789

[24] Palese, A.M., Ringersma, J., Baartman, J.E.M., Peters, P. and Xiloyannis, C. (2015) Runoff and Sediment Yield of Tilled and Spontaneous Grass-Covered Olive Groves Grown on Sloping Land. Soil Research, 53, 542-552.

https://doi.org/10.1071/SR14350

[25] International Telecommunication Union (2013) Overview of the Internet of Things. ITU-T Y-Series Recommendations (Y.2060), Global Information Infrastructure, Internet Protocol Aspects and Next Generation Networks. Geneva, 22 p.

[26] Payero, J.O., Nafchi, A.M., Davis, R. and Khalilian, A. (2017) An Arduino-Based Wireless Sensor Network for Soil Moisture Monitoring Using Decagon EC-5 Sensors. Open Journal of Soil Science, 7, 288-300.

https://doi.org/10.4236/ojss.2017.710021

[27] Payero, J.O., Nafchi, A.M., Khalilian, A., Qiao, X. and Davis, R. (2017) Development of a Low-Cost Internet-of-Things (IoT) System for Monitoring Soil Water Potential Using Watermark 200SS Sensors. Advances in Internet of Things, 7, 71-86. https://doi.org/10.4236/ait.2017.73005

[28] Payero, J.O. (2020) A Wireless Sensor Network for Sensor-Based Irrigation Automation of Cotton. Proceeding of the 2020 Beltwide Cotton Conference, Austin, 8-10 January 2020, 4 p.

[29] U.S. Climate Data (2020). https://www.usclimatedata.com/climate/blackville/south-carolina/united-states/ussc $\underline{0025}$

[30] USDA-NRCS (2020) Web Soil Survey. United States Department of Agriculture (USDA), Natural Resources Conservation Service (NRCS).

https://websoilsurvey.sc.egov.usda.gov/App/WebSoilSurvey.aspx

[31] USDA NRCS (2009) Small Watershed Hydrology WinTR-55 User Guide. USDA, $142 \mathrm{p}$.

https://www.wcc.nrcs.usda.gov/ftpref/wntsc/H\&H/WinTR55/WinTR55UserGuide. pdf

[32] Brakensiek, D.L., Osborn, H.B. and Rawls, W.J. (1979) Field Manual for Research in Agricultural Hydrology. United States Department of Agriculture, Washington DC, $550 \mathrm{p}$.

[33] Frere, M. (1971) Requisite Sampling Frequency for Measuring Nutrient and Pesticide Movement with River Waters. Journal of Agricultural and Food Chemistry, 19, 837-839. https://doi.org/10.1021/jf60177a035 